\title{
Fauna of phlebotomine sand flies (Diptera, Psychodidae) in areas with endemic American cutaneous leishmaniasis in the State of Mato Grosso do Sul, Brazil
}

\author{
Paulo Silva de Almeida ${ }^{1}$, Jhoy Alves Leite ${ }^{1}$, Aldecir Dutra de Araújo ${ }^{1}$, Paulo Mira Batista ${ }^{1}$, Rosineide Barbosa \\ da Silva Touro ${ }^{1}$, Vânia Santos Araújo ${ }^{1}$, Edson José de Souza ${ }^{1}$, João Batista Rodrigues ${ }^{1}$, Gerson Antunes de \\ Oliveira $^{1}$, Jeovaldo Vieira dos Santos ${ }^{1}$, Odival Faccenda ${ }^{2} \&$ José Dilermando Andrade Filho ${ }^{3}$
}

\footnotetext{
${ }^{1}$ Laboratório Regional de Entomologia, Núcleo Regional de Saúde da Secretaria Estadual de Saúde, Rua Hilda Bergo Duarte, 940, Centro, 79806-020 Dourados-MS, Brasil. psilvadealmeida@yahoo.com.br

${ }^{2}$ Universidade Estadual de Dourados, Rod. Dourados Itaum, km 12, Cidade Universitária, 79804-970 Dourados-MS, Brasil. fac@ufms.br ${ }^{3}$ Centro de Pesquisas René Rachou/Fiocruz-MG. Av. Augusto de Lima, 1715, Barro Preto, 30190-002 Belo Horizonte-MG, Brasil. jandrade@cpqrr.fiocruz.br
}

\begin{abstract}
Fauna of phlebotomine sand flies (Diptera, Psychodidae) in areas with endemic American cutaneous leishmaniasis in the State of Mato Grosso do Sul, Brazil. The aim of this study was to investigate the ecological aspects of the main vectors of American cutaneous leishmaniasis (ACL) in four monitoring stations situated in the municipalities of Naviraí, Nova Andradina, Novo Horizonte do Sul and Rio Verde de Mato Grosso. For each monitoring station, the captures of sand flies were undertaken each month from July 2008 to June 2010 using CDC and Shannon traps. The CDC traps were installed simultaneously for three consecutive nights in three collection sites: intradomicile, peridomicile and edge of the forest. A Shannon trap was installed from dusk to 10 $\mathrm{pm}$, inside the forest, one night per month. A total of 7,651 sand flies belonging to nine genera and twenty-nine species were captured. Nyssomyia neivai (52.95\%), Psathyromyia hermanlenti (10.91\%), Psathyromyia runoides (9.16\%), Nyssomyia whitmani (7.95\%), Psathyromyia aragaoi (4.89\%), Nyssomyia antunesi (3.14\%) and Evandromyia bourrouli $(2.20 \%)$ were the most frequent species. Approximately $65 \%$ of the sand flies were collected in the forest environment. The municipalities presented significantly different indexes of species diversity. Naviraí presented the lowest species diversity index, however, it showed the highest abundance. Novo Horizonte do Sul had the highest species diversity index, but the lowest abundance $(<5 \%)$. It is noteworthy the occurrence of vector species of Leishmania in the areas studied, especially in Naviraí, where $N y$. neivai presented high frequencies which may explain the increased number of ACL cases in this municipality.
\end{abstract}

KEYWORDS. Insecta; Neotropical; Phlebotominae; species diversity

Knowing the main vector species found in an area of transmission of American cutaneous leishmaniasis (ACL) is very important in order to understand how the disease is transmitted and thus guide the measures of prevention and control, as well as to evaluate their effectiveness (Ministério da Saúde 2007). In Brazil, there are few studies on the diversity of sand fly species that are vectors of ACL Leishmania. However, bio-ecological studies on suspected or incriminated vector species can contribute to the development of indicators for disease risk assessment.

The sand fly fauna of Mato Grosso do Sul is relatively well known and currently consist of 59 species (Young \& Duncan 1994; Galati et al. 2006; Oliveira et al. 2006; Almeida et al. 2010). Regarding the vectors of ACL agents in Mato Grosso do Sul, studies in the municipality of Corguinho and in the Bodoquena area demonstrated the presence of Nyssomyia whitmani (Antunes \& Coutinho, 1939) (Galati et al. 1996; Galati et al. 2003) and Nyssomyia neivai (Pinto, 1926) in six municipalities of Mato Grosso do Sul (Almeida et al. 2010), which are important species involved in the transmission of ACL leishmaniasis in Brazil (Luz et al. 2000; Andrade Filho et al. 2007; Costa et al. 2007; Saraiva et al.
2010). Recently, in the municipalities of Bela Vista and Bonito the presence of Bichromomyia flaviscutellata (Mangabeira, 1942) in areas with occurrence of Leishmania (Leishmania) amazonensis was confirmed (Nunes et al. 2008; Dorval et al. 2010).

Between January 2008 and July 2010, the SINAN (Sistema de Informações de Agravos de Notificação), Epidemiological Surveillance Service of the Mato Grosso do Sul State Health Secretariat confirmed 388 cases of ACL in 60 municipalities, among them Naviraí, Nova Andradina, Novo Horizonte do Sul and Rio Verde de Mato Grosso. This study aimed to assess: 1) the sand fly fauna, and 2) the ecological aspects of the main vectors of ACL agents in Naviraí, Nova Andradina, Novo Horizonte do Sul and Rio Verde de Mato Grosso municipalities, where the prevalence of ACL is high.

\section{MATERIAL AND METHODS}

Study area. For each municipality, a Monitoring Station (MS) was selected, considering the number of autochthonous human cases of ACL in recent years and the absence of previous researches about the sand flies fauna in these areas. 
Naviraí $\left(23^{\circ} 03^{\prime} 54^{\prime \prime} \mathrm{S}\right.$ and $54^{\circ} 11^{\prime} 26^{\prime \prime} \mathrm{W}, 362$ meters altitude) with an area of $2,193.83 \mathrm{~km}^{2}$ is located in the southwestern region of the state, $350 \mathrm{~km}$ from Campo Grande, the State capital. Its population consists of 46,355 inhabitants (IBGE, 2011). The municipality borders the state of Paraná and the original vegetation was seasonal semi-deciduous forest. The agriculture and commerce are the major economic resources of the municipality. The main crops are sugar cane, beans, lemon, corn and wheat. In this municipality, the entomological survey was conducted near "Usinavi", a sugar cane mill, situated at the farm Santa Maria.

Nova Andradina $\left(22^{\circ} 14^{\prime} 00^{\prime \prime S}\right.$ and $53^{\circ} 20^{\prime} 35^{\prime \prime} \mathrm{W}, 380$ meters altitude) with an area of $4,776.09 \mathrm{~km}^{2}$ is located in the southeastern region, $288 \mathrm{~km}$ from Campo Grande. Its population consists of 45,599 inhabitants (IBGE, 2011). The municipality is part of the Paraná river basin and its original vegetation was seasonal semi-deciduous forest. Livestock (mainly buffalo) and commerce are the major economic resources of the municipality. The main crops are sugar cane and cassava. The CDC light traps were installed in the farm Três Irmãos and the Shannon trap, in a forest fragment, near the neighborhood "COHAB III".

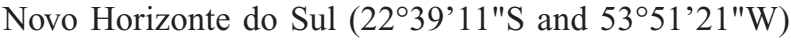
with an area of $849.11 \mathrm{~km}^{2}$ is also located in the southwest region, $303 \mathrm{~km}$ from Campo Grande. The population consists of 4,944 inhabitants (IBGE, 2011). It is also situated in the Paraná river basin and the original vegetation was characterized by seasonal semi-deciduous forest and livestock is the major economic activity of the municipality. The rearing of silkworms and cassava plantations are also widespread in the municipality. The survey was undertaken in an area known as Linha Volta Redonda.

Rio Verde de Mato Grosso (1855’05"S and 54 $50^{\circ} 39^{\prime \prime} \mathrm{W}$ 330 meters altitude) with an area of $8,151.97 \mathrm{~km}^{2}$, is located in the Pantanal, in the north of the State, $201 \mathrm{~km}$ from Campo Grande, its population consisting of 18,892 inhabitants (IBGE 2011). The municipality is located in the Paraguay river basin with a dominant vegetation of Cerrado and Pantanal. Trade and farming are major economic activities in the municipality. Cattle, sheep, horses, wool production and orange, coconut and guava plantations are widespread around the city. The survey was conducted in the Serra Grande Farm resort.

Collection of the sand flies. The survey was conducted from July 2008 to June 2010. In each monitoring station, four locations were sampled: 1) intradomicile; 2) peridomicile; 3 ) edge of the forest and 4) inside the forest. Sand fly collections were carried out with automatic light traps during three consecutive nights on the first, second and third sites, monthly. The Shannon trap was installed from dusk to $10 \mathrm{pm}$, one night per month in the fourth point (forest). The field methodology followed the guidelines of the Manual for the Surveillance of ACL (Ministério da Saúde 2007). Species were identified in the Laboratório Regional de Entomologia de Dourados/SES-MS according to Galati's classification (2003). Abbreviations for the genera follow that proposed by Marcondes (2007).
Analysis of the data. The characteristics of the population studied were described using a single frequency through percentages, tables and graphs. Furthermore, the data were stratified by municipality and point of capture to check the diversity index and proximity among the descriptors, through correspondence analysis (Mingoti 2005).

In order to assess the diversity of the phlebotomine species in the four sites of capture, in each municipality, the Shannon-Wiener index was used (with correction factor and the natural logarithm) according to the number of species occurrences. The $t$ test was used to compare the diversity index. The level of significance was $0.83 \%$, which corresponds to $5 \%$ divided by the number of multiple comparisons (six).

\section{RESULTS AND DISCUSSION}

A total of 7,651 sand flies were captured, belonging to nine genera and twenty-nine species. The most frequent species were: Nyssomyia neivai (52.9\%), Psathyromyia hermanlenti (Martins, Falcão \& Silva, 1970) (10.9\%), Psathyromyia runoides (Fairchild \& Hertig, 1953) (9.2\%), Nyssomyia whitmani (8.0\%), Psathyromyia aragaoi (Costa Lima, 1932) (4.9\%), Nyssomyia antunesi (Coutinho, 1939) (3.1\%), and Evandromyia bourrouli (Barretto \& Coutinho, 1941) $(2.2 \%)$. The other species totalized $8.8 \%$ of the captured sand flies (Table I).

Naviraí presented a high frequency of $\mathrm{Ny}$. neivai (99.6\%). The other species accounted for less than $1 \%$ of the total. Nyssomyia whitmani was only captured at the edge of the forest (Table II). Both species are involved in the transmission of Leishmania protozoa in Brazil (Andrade Filho et al. 2007; Pita-Pereira et al. 2009; Marcondes et al. 2009; Saraiva et al. 2009).

A total of $65.0 \%$ of the sand flies were collected inside the forest, unlike other studies, in which most specimens were found in anthropic environments (Saraiva et al. 2008; Galati et al. 2010). This fact may be due to the use of a Shannon trap in the forest and CDC light traps in the other environments, which demonstrates the importance of using more than one type of trap in studies of sand fly fauna.

The seasonal variation of $N y$. neivai in Naviraí is showed in Fig. 1. The highest frequency of the species occurs in the months that follow periods of heavy rain. This period coincides with the late winter and spring. This result is different than that showed by Galati et al. (2010) in the Iporanga municipality, São Paulo state, where the predominance of the species occurs in the summer, however, it corroborates the observations of Odorizzi \& Galati (2007) in the northwestern region of São Paulo state.

In Nova Andradina, the species Evandromyia lenti (Mangabeira, 1938) showed the highest frequency (47.0\%), followed by Evandromyia termitophila (Martins, Falcão \& Silva, 1964) (19.3\%). Brumptomyia brumpti (Larrouse, 1920), Psathyromyia campograndensis (Oliveira, Andrade Filho, Falcão \& Brazil, 2001), Sciopemyia sordellii (Shan- 
Table I. Phebotominae species collected in four municipalities of the Mato Grosso do Sul state, with CDC and Shannon traps, from July 2008 to June 2010 , and the multiple comparison among the municipalities.

\begin{tabular}{|c|c|c|c|c|c|c|}
\hline \multirow{2}{*}{ Species } & \multicolumn{4}{|c|}{ Municipalities } & \multirow{2}{*}{ Total } & \multirow{2}{*}{ Relative Frequency (\%) } \\
\hline & Naviraí & Nova Andradina & Novo Horizonte do Sul & Rio Verde de Mato Grosso & & \\
\hline Bichromomyia flaviscutellata & 0 & 0 & 0 & 20 & 20 & 0.26 \\
\hline Brumptomyia avellari & 1 & 2 & 23 & 50 & 76 & 0.99 \\
\hline Brumptomyia brumpti & 0 & 5 & 0 & 9 & 14 & 0.18 \\
\hline Brumptomyia pintoi & 0 & 2 & 0 & 3 & 5 & 0.06 \\
\hline Evandromyia bourrouli & 0 & 0 & 4 & 164 & 168 & 2.20 \\
\hline Evandromyia carmelinoi & 0 & 1 & 0 & 0 & 1 & 0.01 \\
\hline Evvandromyia cortelezzii & 0 & 0 & 2 & 1 & 3 & 0.04 \\
\hline Evandromyia lenti & 0 & 39 & 24 & 54 & 117 & 1.53 \\
\hline Evandromyia sallesi & 0 & 0 & 2 & 0 & 2 & 0.03 \\
\hline Evandromyia teratodes & 0 & 1 & 0 & 1 & 2 & 0.03 \\
\hline Evandromyia termitophila & 1 & 16 & 5 & 1 & 23 & 0.30 \\
\hline Lutzomyia longipalpis & 0 & 0 & 0 & 38 & 38 & 0.50 \\
\hline Micropygomyia acanthopharynx & 0 & 0 & 0 & 3 & 3 & 0.04 \\
\hline Micropygomyia peresi & 0 & 0 & 0 & 17 & 17 & 0.22 \\
\hline Nyssomyia antunesi & 0 & 0 & 0 & 240 & 240 & 3.14 \\
\hline Nyssomyia neivai & 4,002 & 2 & 41 & 6 & 4,051 & 52.95 \\
\hline Nyssomyia whitmani & 15 & 0 & 28 & 565 & 608 & 7.95 \\
\hline Pintomyia christenseni & 0 & 0 & 46 & 1 & 47 & 0.61 \\
\hline Psychodopygus davisi & 0 & 0 & 0 & 2 & 2 & 0.03 \\
\hline Pintomyia misionensis & 0 & 0 & 0 & 2 & 2 & 0.03 \\
\hline Pintomyia pessoai & 0 & 1 & 26 & 0 & 27 & 0.35 \\
\hline Psathyromyia aragaoi & 1 & 0 & 26 & 347 & 374 & 4.89 \\
\hline Psathyromyia brasiliensis & 0 & 0 & 0 & 53 & 53 & 0.69 \\
\hline Psathyromyia campograndensis & 0 & 5 & 4 & 59 & 68 & 0.89 \\
\hline Psathyromyia hermanlenti & 0 & 0 & 2 & 833 & 835 & 10.91 \\
\hline Psathyromyia punctigeniculata & 0 & 4 & 4 & 4 & 12 & 0.16 \\
\hline Psathyromyia runoides & 0 & 0 & 0 & 701 & 701 & 9.16 \\
\hline Psathyromyia shannoni & 0 & 0 & 98 & 17 & 115 & 1.50 \\
\hline Sciopemyia sordellii & 0 & 5 & 12 & 10 & 27 & 0.35 \\
\hline Total & 4,020 & 83 & 347 & 3,201 & 7,651 & 100.00 \\
\hline$\%$ & 52.54 & 1.08 & 4.54 & 41.84 & 100.00 & - \\
\hline Shannon-W Index & 0.310 & 1.689 & 2.333 & 2.075 & - & - \\
\hline \multicolumn{3}{|c|}{ Multiple comparisons among the municipalities } & $\mathrm{t}$ & g.1. & p-value & Sig. \\
\hline \multicolumn{3}{|l|}{ Naviraí x Nova Andradina } & -12.959 & 83.42 & $<0.001$ & * \\
\hline \multicolumn{3}{|l|}{ Naviraí x Novo Horizonte do Sul } & -46.316 & 360.15 & $<0.001$ & * \\
\hline \multicolumn{3}{|l|}{ Naviraí x Rio Verde do MT } & -105.76 & 4005.6 & $<0.001$ & $*$ \\
\hline \multicolumn{3}{|c|}{ Nova Andradina x Novo Horizonte do Sul } & -3.993 & 106.6 & $<0.001$ & $*$ \\
\hline \multicolumn{3}{|l|}{ Nova Andradina $\mathrm{x}$ Rio Verde do MT } & -2.990 & 86.5 & $<0.004$ & $*$ \\
\hline \multicolumn{3}{|c|}{ Novo Horizonte do Sul x Rio Verde do MT } & 3.126 & 457.5 & $<0.002$ & $*$ \\
\hline
\end{tabular}

* Significant with $\mathrm{p}<0.0084$

non \& Del Pont, 1927), all with 6.0\%, and Psathyromyia punctigeniculata, with $4.8 \%$, presented distinct frequencies from the other species, which together accounted for $10.9 \%$ of the species captured (Table III). Evandromyia lenti was found naturally infected with Leishmania braziliensis in Minas Gerais (Margonari et al. 2010), and Sherlock (1996) suggests that this species may be involved in the transmission of canine visceral leishmaniasis in the State of Bahia.

Psathyromyia shannoni (Dyar, 1929) was the species with the greatest abundance (28.2\%) in Novo Horizonte do Sul, followed by Pintomyia christenseni (Young \& Duncan, 1994) (13.3\%), Ny. neivai (11.8\%), Ny. whitmani (8.1\%), Pa. aragaoi and Pintomyia pessoai (Barretto \& Coutinho, 1940), both with $7.5 \%$, Ev. lenti (6.9\%) and Brumptomyia avellari (Costa Lima, 1922) (6.6\%). The other species accounted for the remaining $10.1 \%$. Psathyromyia shannoni was predominant inside the forest. This species has been found naturally infected in several countries (Young \& Duncan 1994) and may be involved in the transmission of Leishmania mexicana in Mexico (Sanchéz-García et al. 2010). It is also important to empha- 
Table II. Phebotominae species collected in four municipalities of the state of Mato Grosso do Sul, with CDC and Shannon traps, from July 2008 to June 2010, and multiple comparison among the four collection sites.

\begin{tabular}{|c|c|c|c|c|c|c|}
\hline \multirow{2}{*}{ Species } & \multicolumn{4}{|c|}{ Collection sites } & \multirow{2}{*}{ Total } & \multirow{2}{*}{ Relative Frequency (\%) } \\
\hline & Intra domicile & Peri domicile & Edge of the forest & Inside the forest & & \\
\hline Bi. flaviscutellata & 0 & 6 & 14 & 0 & 20 & 0.26 \\
\hline Br. avellari & 1 & 20 & 42 & 13 & 76 & 0.99 \\
\hline Br. brumpti & 0 & 3 & 8 & 3 & 14 & 0.18 \\
\hline Br. pintoi & 0 & 0 & 4 & 1 & 5 & 0.06 \\
\hline Ev. bourrouli & 0 & 46 & 116 & 6 & 168 & 2.20 \\
\hline Ev. carmelinoi & 0 & 0 & 1 & 0 & 1 & 0.01 \\
\hline Ev. cortelezzii & 1 & 0 & 2 & 0 & 3 & 0.04 \\
\hline Ev. lenti & 21 & 39 & 44 & 13 & 117 & 1.53 \\
\hline Ev. sallesi & 0 & 0 & 0 & 2 & 2 & 0.03 \\
\hline Ev. teratodes & 0 & 2 & 0 & 0 & 2 & 0.03 \\
\hline Ev. termitophila & 2 & 20 & 1 & 0 & 23 & 0.30 \\
\hline Lu. longipalpis & 4 & 8 & 12 & 14 & 38 & 0.50 \\
\hline Mi. acanthopharynx & 1 & 2 & 0 & 0 & 3 & 0.04 \\
\hline Mi. peresi & 0 & 3 & 14 & 0 & 17 & 0.22 \\
\hline Ny. antunesi & 4 & 54 & 179 & 3 & 240 & 3.14 \\
\hline Ny. neivai & 290 & 539 & 607 & 2615 & 4,051 & 52.95 \\
\hline Ny. whitmani & 9 & 173 & 342 & 84 & 608 & 7.95 \\
\hline Pi. christenseni & 2 & 5 & 17 & 23 & 47 & 0.61 \\
\hline Ps. davisi & 0 & 0 & 2 & 0 & 2 & 0.03 \\
\hline Pi. misionensis & 0 & 0 & 0 & 2 & 2 & 0.03 \\
\hline Pi. pessoai & 1 & 1 & 9 & 16 & 27 & 0.35 \\
\hline Pa. aragaoi & 5 & 84 & 274 & 11 & 374 & 4.89 \\
\hline Pa. brasiliensis & 1 & 24 & 28 & 0 & 53 & 0.69 \\
\hline Pa. campograndensis & 3 & 18 & 34 & 13 & 68 & 0.89 \\
\hline Pa. hermanlenti & 25 & 164 & 618 & 38 & 835 & 10.91 \\
\hline Pa. punctigeniculata & 1 & 1 & 2 & 8 & 12 & 0.16 \\
\hline Pa. runoides & 22 & 146 & 521 & 12 & 701 & 9.16 \\
\hline Pa. shannoni & 11 & 5 & 15 & 84 & 115 & 1.50 \\
\hline Sc. sordellii & 1 & 9 & 13 & 4 & 27 & 0.35 \\
\hline Total & 405 & 1,362 & 2,919 & 2,965 & 7,651 & 100 \\
\hline$\%$ & 5.29 & 17.80 & 38.15 & 38.75 & 100 & - \\
\hline Shannon-W Index & 1.221 & 2.060 & 2.171 & 0.635 & - & - \\
\hline \multicolumn{3}{|c|}{ Multiple comparisons among the sites } & $\mathrm{T}$ & g.1. & p-value & Sig. \\
\hline \multicolumn{3}{|l|}{ Intra $\mathrm{x}$ Peri } & -10.108 & 558.50 & $<0.001$ & $*$ \\
\hline \multicolumn{3}{|l|}{ Intra $x$ Edge of forest } & -12.082 & 452.79 & $<0.001$ & $*$ \\
\hline \multicolumn{3}{|l|}{ Intra $\mathrm{x}$ Forest } & 7.247 & 507.49 & $<0.001$ & $*$ \\
\hline \multicolumn{3}{|l|}{ Peri $x$ Edge of forest } & -2.966 & $2,265.30$ & $<0.004$ & $*$ \\
\hline \multicolumn{3}{|l|}{ Peri $x$ Forest } & 34.028 & $3,148.80$ & $<0.001$ & $*$ \\
\hline \multicolumn{3}{|l|}{ Edge of forest $\mathrm{x}$ Forest } & 47.610 & $5,256.70$ & $<0.001$ & $*$ \\
\hline
\end{tabular}

* Significant with $\mathrm{p}<0.0084$.

size the predominance of $N y$. neivai in the intradomicile environment.

In Rio Verde do Mato Grosso, the species with the highest frequency was Pa. hermanlenti (26.0\%), followed by $P a$. runoides $(21.9 \%)$, Ny. whitmani $(17.7 \%)$, Pa. aragaoi (10.8\%), Ny. antunesi (7.5\%), Ev. bourrouli (5.1\%), Pa. campograndensis $(1.9 \%)$ and Ev. lenti $(1,7 \%)$. The other species totalized $7.4 \%$. The majority of specimens were collected at the edge of the forest (68.4\%). Psathyromyia hermanlenti and $P a$. runoides were more frequent in the intradomicile environment (Table III). This is the first report of Pa. runoides in the Mato Grosso do Sul state. The vectors species of Leishmania (Viannia) spp. collected in Rio Verde do Mato Grosso were $N y$. whitmani and $N y$. antunesi, the latter presenting a highly anthropophilic behavior (Andrade Filho et al. 2001) and they were found naturally infected by flagellates in the State of Pará (Ryan et al. 1984; Silveira et al. 2002). Bichromomyia flaviscutellata, a species involved in the transmission of Leishmania (Leishmania) amazonensis in several regions of Brazil, including Mato Grosso do Sul (Lainson \& Shaw 1968; Shaw \& Lainson 1968; Dorval et al. 2010), was also captured. 
Table III. Phebotominae species captured from July 2008 to June 2010, in the municipalities of Naviraí, Nova Andradina, Novo Horizonte do Sul and Rio Verde de Mato Grosso, in the state of Mato Grosso do Sul.

\begin{tabular}{|c|c|c|c|c|c|c|}
\hline \multirow{2}{*}{ Species } & \multicolumn{4}{|c|}{ Collection sites } & \multirow{2}{*}{ Total } & \multirow{2}{*}{ Relative Frequency (\%) } \\
\hline & Intra domicile & Peri domicile & Edge of the forest & Inside of the forest & & \\
\hline \multicolumn{7}{|l|}{ Naviraí } \\
\hline Br. avellari & 0 & 1 & 0 & 0 & 1 & 0.03 \\
\hline Ev. termitophila & 1 & 0 & 0 & 0 & 1 & 0.03 \\
\hline Ny. neivai & 274 & 29 & 592 & 2,607 & 4,002 & 99.55 \\
\hline Ny. whitmani & 0 & 0 & 15 & 0 & 15 & 0.36 \\
\hline Ps. aragaoi & 1 & 0 & 0 & 0 & 1 & 0.03 \\
\hline Total & 276 & 530 & 607 & 2,607 & 4,020 & 100.00 \\
\hline$\%$ & 6.87 & 13.18 & 15.10 & 64.85 & 100.00 & - \\
\hline \multicolumn{7}{|l|}{ Nova Andradina } \\
\hline Br. avellari & 0 & 0 & 0 & 2 & 2 & 2.41 \\
\hline Br. brumpti & 0 & 1 & 1 & 3 & 5 & 6.02 \\
\hline Br. pintoi & 0 & 0 & 1 & 1 & 2 & 2.41 \\
\hline Ev. carmelinoi & 0 & 0 & 1 & 0 & 1 & 1.21 \\
\hline Ev. lenti & 4 & 11 & 14 & 10 & 39 & 46.99 \\
\hline Ev. teratodes & 0 & 1 & 0 & 0 & 1 & 1.21 \\
\hline Ev. termitophila & 1 & 15 & 0 & 0 & 16 & 19.27 \\
\hline Ny. neivai & 0 & 0 & 1 & 1 & 2 & 2.41 \\
\hline Pi. pessoai & 0 & 1 & 0 & 0 & 1 & 1.20 \\
\hline Pa. campograndensis & 1 & 0 & 0 & 4 & 5 & 6.02 \\
\hline Pa. punctigeniculata & 0 & 0 & 0 & 4 & 4 & 4.82 \\
\hline Sc. sordellii & 0 & 2 & 0 & 3 & 5 & 6.02 \\
\hline Total & 6 & 31 & 18 & 28 & 83 & 100.00 \\
\hline$\%$ & 7.23 & 37.35 & 21.69 & 33.73 & 100.00 & - \\
\hline
\end{tabular}

\begin{tabular}{|c|c|c|c|c|c|c|}
\hline \multirow{2}{*}{\multicolumn{7}{|c|}{ Novo Horizonte do Sul }} \\
\hline & & & & & & \\
\hline Br. avellari & 1 & 2 & 17 & 3 & 23 & 6.63 \\
\hline Ev. bourrouli & 0 & 1 & 3 & 0 & 4 & 1.15 \\
\hline Ev. cortelezzii & 1 & 0 & 1 & 0 & 2 & 0.58 \\
\hline Ev. lenti & 9 & 9 & 5 & 1 & 24 & 6.92 \\
\hline Ev. sallesi & 0 & 0 & 0 & 2 & 2 & 0.58 \\
\hline Ev. termitophila & 0 & 4 & 1 & 0 & 5 & 1.44 \\
\hline Ny. neivai & 15 & 9 & 11 & 6 & 41 & 11.82 \\
\hline Ny. whitmani & 4 & 4 & 10 & 10 & 28 & 8.07 \\
\hline Pi. christenseni & 2 & 5 & 16 & 23 & 46 & 13.26 \\
\hline Pi. pessoai & 1 & 0 & 9 & 16 & 26 & 7.49 \\
\hline Pa. aragaoi & 1 & 7 & 16 & 2 & 26 & 7.49 \\
\hline Pa. campograndensis & 0 & 0 & 2 & 2 & 4 & 1.15 \\
\hline Pa. hermanlenti & 0 & 2 & 0 & 0 & 2 & 0.58 \\
\hline Pa. punctigeniculata & 0 & 0 & 0 & 4 & 4 & 1.15 \\
\hline Pa. shannoni & 10 & 3 & 8 & 77 & 98 & 28.24 \\
\hline Sc. sordellii & 0 & 5 & 6 & 1 & 12 & 3.46 \\
\hline Total & 44 & 51 & 105 & 147 & 347 & 100.00 \\
\hline$\%$ & 12.68 & 14.70 & 30.26 & 42.36 & 100.00 & - \\
\hline \multicolumn{7}{|c|}{ Rio Verde de Mato Grosso } \\
\hline Bi. flaviscutellata & 0 & 6 & 14 & 0 & 20 & 0.63 \\
\hline Br. avellari & 0 & 17 & 25 & 8 & 50 & 1.56 \\
\hline Br. brumpti & 0 & 2 & 7 & 0 & 9 & 0.28 \\
\hline Br. pintoi & 0 & 0 & 3 & 0 & 3 & 0.09 \\
\hline Ev. bourrouli & 0 & 45 & 113 & 6 & 164 & 5.12 \\
\hline Ev. cortelezzii & 0 & 0 & 1 & 0 & 1 & 0.03 \\
\hline Ev. lenti & 8 & 19 & 25 & 2 & 54 & 1.69 \\
\hline Ev. teratodes & 0 & 1 & 0 & 0 & 1 & 0.03 \\
\hline Ev. termitophila & 0 & 1 & 0 & 0 & 1 & 0.03 \\
\hline Lu. longipalpis & 4 & 8 & 12 & 14 & 38 & 1.19 \\
\hline Mi. acanthophargynx & 1 & 2 & 0 & 0 & 3 & 0.09 \\
\hline
\end{tabular}


Table III. Continued.

\begin{tabular}{|c|c|c|c|c|c|c|}
\hline \multirow{2}{*}{ Species } & \multicolumn{4}{|c|}{ Collection sites } & \multirow{2}{*}{ Total } & \multirow{2}{*}{ Relative Frequency (\%) } \\
\hline & Intra domicile & Peri domicile & Edge of the forest & Inside of the forest & & \\
\hline Mi. peresi & 0 & 3 & 14 & 0 & 17 & 0.53 \\
\hline Ny. antunesi & 4 & 54 & 179 & 3 & 240 & 7.50 \\
\hline Ny. neivai & 1 & 1 & 3 & 1 & 6 & 0.19 \\
\hline Ny. whitmani & 5 & 169 & 317 & 74 & 565 & 17.65 \\
\hline Pi. christenseni & 0 & 0 & 1 & 0 & 1 & 0.03 \\
\hline Ps. davisi & 0 & 0 & 2 & 0 & 2 & 0.06 \\
\hline Pi. misionensis & 0 & 0 & 0 & 2 & 2 & 0.06 \\
\hline Pa. aragaoi & 3 & 77 & 258 & 9 & 347 & 10.84 \\
\hline Pa. brasiliensis & 1 & 24 & 28 & 0 & 53 & 1.66 \\
\hline Pa. campograndensis & 2 & 18 & 32 & 7 & 59 & 1.85 \\
\hline Pa. hermanlenti & 25 & 152 & 618 & 38 & 833 & 26.02 \\
\hline Pa. punctigeniculata & 1 & 1 & 2 & 0 & 4 & 0.13 \\
\hline Pa. runoides & 22 & 146 & 521 & 12 & 701 & 21.90 \\
\hline Pa. shannoni & 1 & 2 & 7 & 7 & 17 & 0.53 \\
\hline Sc. sordellii & 1 & 2 & 7 & 0 & 10 & 0.31 \\
\hline Total & 79 & 750 & 2,189 & 183 & 3,201 & 100.00 \\
\hline$\%$ & 2.47 & 23.43 & 68.38 & 5.72 & 100.00 & - \\
\hline
\end{tabular}

During the two years of the study, the seasonal distribution of $N y$. whitmani in Rio Verde de Mato Grosso showed a higher density in drier periods (fall and winter) (Fig. 1), as occurred in the Bodoquena and Corguinho municipalities, both in Mato Grosso do Sul state (Galati et al. 1996; Galati et al. 2003), and Maringá, in Paraná state (Teodoro et al. 2003).

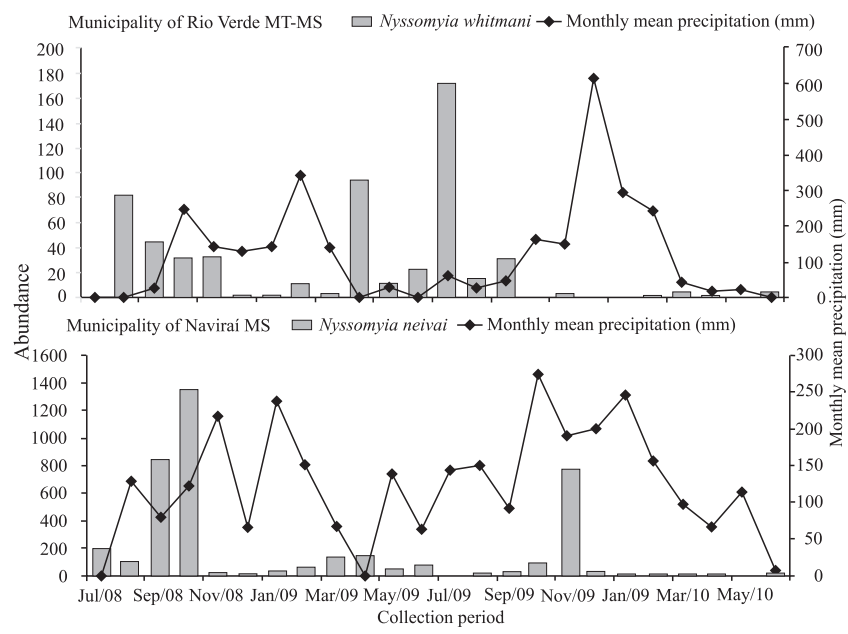

Fig. 1. Monthly variation of the abundance of Nyssomyia whitmani and Nyssomyia neivai in relation to the monthly mean precipitation in Rio Verde de Mato Grosso and Nivaraí municipalities, from July 2008 to June 2010.

The municipalities presented significantly different species diversity indexes (Table I), with Naviraí, which presented the highest frequency of specimens $(52.6 \%)$, showing the lowest value, influenced by the abundance of $N y$. neivai (Table III). Nova Andradina had less than 2\% of specimens captured, and showed the second lowest diversity value (Table I,
Fig. 2). Novo Horizonte do Sul had the highest species diversity, although its abundance was lower than 5\% (Table I, Fig. 2) and Rio Verde do Mato Grosso presented the second highest diversity and abundance, with approximately $42 \%$ of the sand flies captured (Table I, Fig. 2).

The correspondence analysis (Fig. 2) revealed that the position of the different species is not close to the center, which means that their prevalence differs among the municipalities. The incidence is similar in Novo Horizonte do Sul and Nova Andradina. Naviraí had an incidence of few spe-

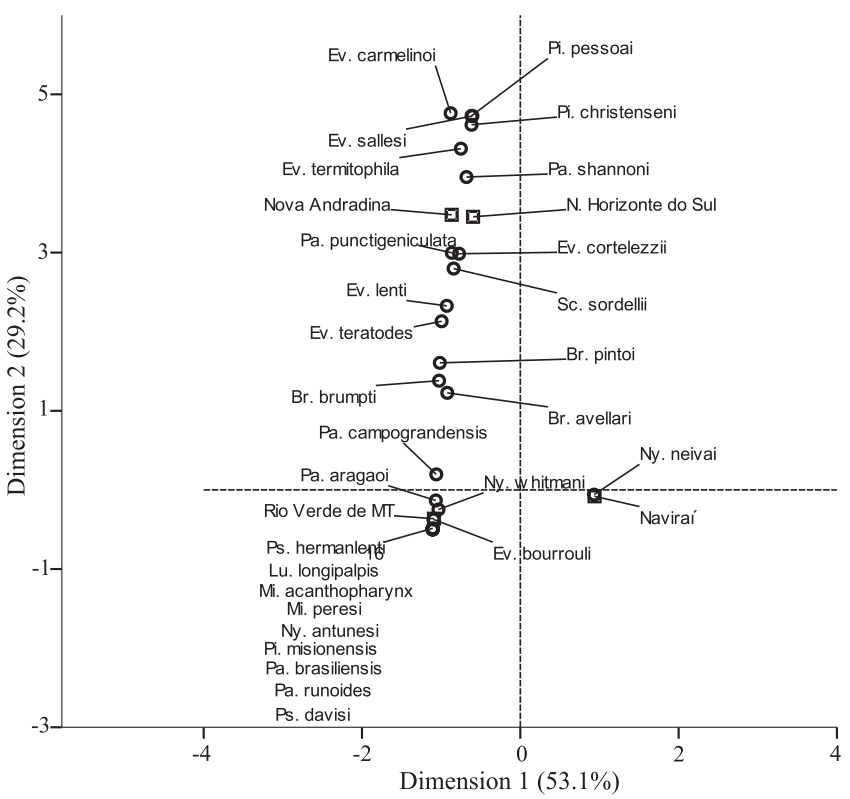

Fig. 2. Results of correspondence analysis among the phebotomine species and the municipalities of Naviraí, Nova Andradina, Novo Horizonte do Sul and Rio Verde de Mato Grosso from July 2008 to June 2010. ( $\square$ ) Municipality, (O) species. 
cies, but is associated with the most abundant species, $N y$. neivai. Rio Verde de Mato Grosso is associated with more species and greater abundance.

Nyssomyia neivai was the most frequent and abundant species. It was present in all ecotypes surveyed in the state of Mato Grosso do Sul. This observation confirms the results obtained by Massafera et al. (2005) and Silva et al. (2008) in the State of Paraná. In the state of São Paulo, Condino et al. (1998) also observed a higher density of $N y$. neivai in the city of Teodoro Sampaio. In the city of Piçarras, in the state of Santa Catarina, Marcondes et al. (2005) observed the predominance of $N y$. neivai in areas with occurrence of ACL.

Nyssomyia whitmani was the fourth most frequently captured species (Table I), occurring in Naviraí, Novo Horizonte do Sul and Rio Verde do Mato Grosso and was considered as a potential vector of Leishmania braziliensis in Mato Grosso do Sul (Galati et al. 1996). This species was more abundant in environments with anthropic modifications, such as peridomicile and the edge of the forest.

Despite the use of different traps, the diversity is distinct among the different collecting sites, being higher in the edge of the forest, followed by peridomicile and intradomicile. The lowest diversity was found inside the forest. The diversity index was statistically different for all comparisons between two environments (Table II). The diversity of sand flies of the four municipalities should be related, probably with peculiar characteristics of each, such as geographical location, vegetation and climate, important factors for the faunal composition.

The geometric proximity between the site of capture and species of sand flies is represented by Fig. 3. Dimension 1 explains almost all of the variation $(92.7 \%)$, allowing the results to

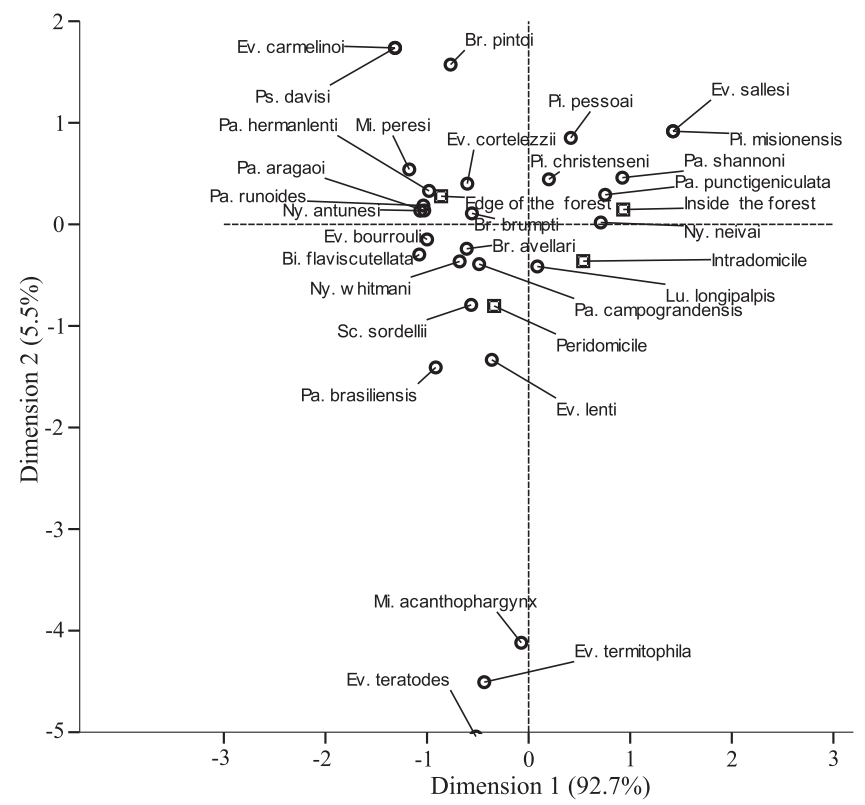

Fig. 3. Results of correspondence analysis among the phebotomine species and the environment in which they were collected in the municipalities of Naviraí, Nova Andradina, Novo Horizonte do Sul and Rio Verde de Mato Grosso, from July 2008 to June 2010. ( $\square$ ) Collection sites, (O) species. be read horizontally, from left to right. The species located to the left of the center are associated with the edge of the forest and peridomicile, and those located to the right of the center, with intradomicile and inside the forest and, therefore, they represent the most abundant species there. Near the center, indicating that there is no trend, i.e., the abundance is divided proportionally among the environments, few species appear in this location. Lutzomyia longipalpis (Lutz \& Neiva, 1912) and Pi. christenseni appear closer to the center, being their frequencies proportional in all places of capture. On the other hand, the majority of species are found outside the center, showing that their incidence is not proportionally equal among the sites of capture.

From 2001 to 2010, Naviraí reported 82 cases of ACL, Nova Andradina reported 41, Novo Horizonte do Sul reported 48 and Rio Verde de Mato Grosso reported 51 cases (Sinan 2011). Important vector species of ACL agents were found in these municipalities, especially $N y$. neivai in Naviraí, which may explain the high number of cases of ACL in this municipality, suggesting that this species may be responsible for the disease transmission in this region.

\section{ACKNOWLEDGEMENTS}

To the technicians from the Ministry of Health for their collaboration in the field research: Agabito Arguelho, in the municipality of Novo Horizonte do Sul and the colleagues from Laboratório Regional de Entomologia de Dourados, Ademar Dimas Ferreira, José Oliveira da Silva, Nilza Sizue Fukuda Nogueira Mariano and Maria Aparecida Ferreira de Souza, for helping in the mounting and in the identification of the sand flies. To Fundação de Amparo à Pesquisa do Estado de Minas Gerais (FAPEMIG) for financial support.

\section{REFERENCES}

Almeida, P.S., Nascimento, J.C., Ferreira, A.D., Minzão, L.D., Portes, F., Miranda, A.M., Faccenda, O.\& Andrade Filho, J.D. 2010. Espécies de flebotomíneos (Diptera: Psychodidae) coletadas em ambiente urbano em municípios com transmissão de Leishmaniose Visceral do Estado de Mato Grosso do Sul, Brasil. Revista Brasileira de Entomologia 54: 304-310.

Andrade Filho, J.D., Galati, E.A.B. \& Falcão, A.L. 2007. Nyssomyia intermedia (Lutz \& Neiva, 1912) and Nyssomyia neivai (Pinto, 1916) (Diptera: Psychodidae: Phlebotominae) geographical distribution and epidemiological importace. Memórias do Instituto Oswaldo Cruz 102: 481-487.

Andrade Filho, J.D., Valente, M.B., Andrade, W.A., Brazil, R.P. \& Falcão, A.L. 2001. Flebotomíneos do Estado de Tocantins, Brasil (Diptera: Psychodidae). Revista da Sociedade Brasileira de Medicina Tropical 34: 323-329.

Condino, M.L., Sampaio, S.M., Henriques, L.F., Galati, E.A.B., Wanderley, D.M.V. \& Corrêa, F.M. A. 1998. Leishmaniose tegumentar americana: Flebotomíneos de área de transmissão no município de Teodoro Sampaio, Região Sudoeste do Estado de São Paulo, Brasil. Revista da Sociedade Brasileira de Medicina Tropical 31: 355-360.

Costa, S.M., Cechinel, M., Bandeira, V., Zannuncio, J.C., Lainson, R. \& Rangel, E.F. 2007. Lutzomyia (Nyssomyia) whitmani s.l. (Antunes \& Coutinho, 1939) (Diptera: Psychodidae: Phlebotominae): geographical distribution and the epidemiology of American cutaneous leishmaniasis in Brazil Minireview. Memórias do Instituto Oswaldo Cruz 102: 149-153. 
Dorval, M.E.C., Alves, T.P., Cristaldo, G., Rocha, H.C., Alves, M.A., Oshiro, E.T., Oliveira, A.G., Brazil, R.P., Galati, E.A.B. \& Cunha, R.V. 2010. Sand fly captures with Disney traps in area of occurrence of Leishmania (Leishmania) amazonensis in the State of Mato Grosso do Sul, mid-western Brazil. Revista da Sociedade Brasileira de Medicina Tropical 43: 491-495.

Galati, E.A.B. 2003. Classificação de Phlebotominae, p. 23-51. In: Rangel, E.F. \& Lainson, R. (eds.). Flebotomíneos do Brasil. Rio de Janeiro, Fiocruz.

Galati, E.A.B., Marassá, A.M., Gonçalves-Andrade, R.M., Bueno, E.F.M., Paiva, B.R. \& Malafronte, R.S. 2010. Nyssomyia intermedia (Lutz \& Neiva) and Nyssomyia neivai (Pinto) (Diptera, Psychodidae, Phlebotominae) in a sympatric area: seasonal and nocturnal hourly rhythm in black and white modified Shannon traps. Revista Brasileira de Entomologia 54: 677-686.

Galati, E.A.B.; Nunes, V.L.B., Cristaldo, G. \& Rocha, H.C. 2003. Aspectos do comportamento da fauna flebotomínea (Diptera: Psychodidae) em foco de leishmaniose visceral e tegumentar na Serra da Bodoquena e área adjacente, Estado de Mato Grosso do Sul, Brasil. Revista de Patologia Tropical 32: 235-261.

Galati, E.A.B., Nunes, V.L.B., Dorval, M.E.C., Oshiro, E.T., Cristaldo, G., Rocha, H.C., Espíndola, M.A., Rocha, H.C. \& Garcia, N.B. 1996. Estudo dos flebotomíneos (Diptera: Psychodidae) em área de leishmaniose tegumentar, no Estado de Mato Grosso do Sul, Brasil. Revista de Saúde Pública 30: 115-128.

Galati, E.A.B., Nunes, V.L.B., Bogiani, P.C., Dorval, M.E.C., Cristaldo, G., Rocha, H.C., Oshiro, E.T. \& Damasceno-Junior, G.A. 2006. Phlebotomines (Diptera: Psychodidae) in forested areas of the Serra da Bodoquena, state of Mato Grosso do Sul, Brazil. Memórias do Instituto Oswaldo Cruz 101:175-193.

IBGE. Available at: http://www.ibge.gov.br/cidadesat/topwindow.htm?1 (accessed 16 February 2011).

Lainson, R. \& Shaw, J.J. 1968. Leishmaniasis in Brazil. I - Observations on enzootic rodent leishmaniasis - Incrimination of Lutzomyia flaviscutellata (Mangabeira) as the vector in the lower Amazonian basin. Transactions of the Royal Society of Tropical Medicine and Hygiene 62: 385-395.

Luz, E., Membrive, N., Castro, E.A., Dereure, J., Pratlong, F., Dedet, A., Pandey, A. \& Thomaz-Soccol, V.2000. Lutzomyia whitmani (Diptera: Psychodidae) as vector of Leishmania $(V$.$) braziliensis in Paraná state, southern Brazil.$ Annals of Tropical Medicine and Parasitology 94: 623-631.

Marcondes, C.B. 2007. A proposal of generic and subgeneric abbreviations for Phlebotomine sand flies (Diptera: Psychodidae: Phlebotominae) of the world. Entomological News 118: 351-356.

Marcondes, C.B., Bittencourt, I.A., Stoco, P.H., Eger, I., Grisard, E.C. \& Steindel, M. 2009. Natural infection of Nyssomyia neivai (Pinto, 1926) (Diptera: Psychodidae, Phlebotominae) by Leishmania (Viannia) spp. in Brazil. Transactions of the Royal Society of Tropical Medicine and Hygiene 103: 1093-1097.

Marcondes, C.B., Conceição, M.B.F., Portes, M.G.T. \& Simão, B.P. 2005. Phlebotomine sandflies in a focus of dermal leishmaniasis in the eastern region of the Brazilian State of Santa Catarina - preliminary results (Diptera: Psychodidae). Revista da Sociedade Brasileira de Medicina Tropical 38: 353-355.

Margonari, C., Soares, R.P., Andrade Filho, J.D., Xavier, D.C., Saraiva, L., Fonseca, A.L., Silva, R.A., Oliveira, M.E., Borges, E.C., Sanguinette, C.C. \& Melo, M.N. 2010. Phlebotomine Sand Flies (Diptera: Psychodidae) and Leishmania Infection in Gafanhoto Park, Divinópolis, Brazil. Journal of Medical Entomology 47: 1212-1219.

Massafera, R., Silva, A.M., Carvalho, A.P., Santos, D.R., Galati, E.A.B. \& Teodoro, U. 2005. Fauna de flebotomíneos do município de Bandeirantes, no Estado do Paraná. Revista de Saúde Pública 39: 571-577.

Mingoti, S.A. 2005. Análise de dados através de métodos de estatísticas multivariada: uma abordagem aplicada. Belo Horizonte, Editora da Universidade Federal de Minas Gerais, 297 p.

Ministério da Saúde. 2007. Manual de Vigilância e Controle da Leishmaniose Tegumentar Americana. Brasília, 179 p

Nunes, V.L.B., Galati, E.A.B., Cardozo, C., Roca, M.E.G., Andrade, A.R.O. Santos, M.F. C., Aquino R. B. \& Rosa, D. 2008. Study of phlebotomines (Diptera, Psychodidae) in the urban area of Bonito municipality, Mato
Grosso do Sul, Brazil. Revista Brasileira de Entomologia 52: 446-451.

Odorizzi, R.F.N. \& Galati, E.A.B. 2007. Flebotomíneos de várzea do rio Aguapeí, região noroeste do estado de São Paulo, Brasil. Revista de Saúde Pública 4: 645-652.

Oliveira, A.G., Galati, E.A.B., Oliveira, O., Oliveira, G.R., Espíndola, A.C., Dorval, M.E.C. \& Brazil, R.P. 2006. Abundance of Lutzomyia longipalpis (Díptera: Psychodidae: Phlebotominae) and urban transmission of visceral leismaniasis in Campo Grande, state of Mato Grosso do Sul, Brazil. Memórias do Instituto Oswaldo Cruz 101: 869-874.

Pita-Pereira, D., Souza, G.D., Zwetsch, A.; Alves, C.R.; Britto, C. \& Rangel, E.F. 2009. First report of Lutzomyia (Nyssomyia) neivai (Diptera: Psychodidae: Phlebotominae) Naturally Infected by Leishmania (Viannia) braziliensis in a periurban area of South Brazil using a multiplex polymerase chain reaction assay. American Journal of Tropical Medicine and Hygiene 80: 593-595.

Ryan, L., Silveira F.T., Lainson, R. \& Shaw, J.J. 1984. Leishmanial infections in Lutzomyia longipalpis and Lu. antunesi (Diptera: Psychodidae) on the island of Marajó, Pará State, Brazil. Transactions of the Royal Society of Tropical Medicine and Hygiene 78: 547-548.

Sánchez-García, L., Berzunza-Cruz M.; Becker-Fauser, I. \&, RebollarTéllez, E.A. 2010. Sand flies naturally infected by Leishmania (L.) mexicana in the peri-urban area of Chetumal city, Quintana Roo, México. Transactions of the Royal Society of Tropical Medicine and Hygiene 104: 406-411.

Saraiva, L., Carvalho, G.M.L., Sanguinette, C.C., Carvalho, D.A.A., Falcão, A.L. \& Andrade Filho, J.D. 2008. Sandflies (Diptera: Psychodidae: Phlebotominae) collected on the banks of the Velhas River in the state of Minas Gerais, Brazil. Memórias do Instituto Oswaldo Cruz 103: 843-846.

Saraiva, L., Carvalho G.M.L., Quaresma P.F., Lima A.C.V.M.R., Falcão, A.L. \& Andrade Filho, J.D. 2009. Natural infection of Nyssomyia neivai (Pinto, 1926) and Evandromyia sallesi (Galvão \& Coutinho, 1939) (Diptera: Psychodidae) by Leishmania infantum chagasi Cunha and Chagas, 1937 in Minas Gerais, Brazil. Journal of Medical Entomology 49: 1159-1163.

Saraiva, L., Andrade Filho, J.D., Silva, S.O., Andrade A.S.R. \& Melo, M.N. 2010. The molecular detection of different Leishmania species within sand flies from a cutaneous and visceral leishmaniasis sympatric area in Southeastern Brazil. Memórias do Instituto Oswaldo Cruz 105: 1033-1039.

Shaw, J.J. \& Lainson, R. 1968. Leishmaniasis in Brazil: II Observations on enzootic rodent leishmaniasis in the lower amazon region - The feeding habitats of the vector, Lutzomyia flaviscutellata in reference to man, rodents and other animals. Transactions of the Royal Society of Tropical Medicine and Hygiene 62: 396-405.

Sherlock, I.A. 1996. Ecological interactions of visceral leishmaniasis in the state of Bahia, Brazil. Memórias do Instituto Oswaldo Cruz 91: 671-683.

Silva, A.M., Camargo, N.J., Santos, D.R., Massafera, R., Ferreira, A.C., Postal, C., Cristóvão, E.C., Konolsaisen, Jr. J.J., Bisetto, C., Perinazo, R., Teodoro, U. \& E.A.B. Galati. 2008. Diversidade, Distribuição e Abundância de Flebotomíneos (Diptera: Psychodidae) no Paraná. Neotropical Entomology 37: 209-225.

Silveira, F.T., Ishikawa, E.A., De Souza, A.A. \& Lainson, R. 2002. An outbreak of cutaneous leishmaniasis among soldiers in Belém, Pará State, Brazil, caused by Leishmania (Viannia) lindenbergi n. sp. A new leishmanial parasite of man in the Amazon region. Parasite 9: 43-50.

SINAN. 2011. Available at http://dtr2004.saude.gov.br/sinanweb/ (accessed on 16 April 2011)

Teodoro, U., Albertonb, D., Kühl, J.B., Santos, E.S., Santos, D.R., Santos, A.R., Oliveira, O. \& Verzignassi, T. G. 2003. Ecology of Lutzomyia (Nyssomyia) whitmani in an urban area in Brazil. Revista de Saúde Pública 37: 651-656.

Young, D.G., \& Duncan, M.A. 1994. Guide to the Identification and Geographic Distribution of Lutzomyia Sand Flies in México, the West Indies, Central and South America (Diptera: Psychodidae). Memoirs of the American Entomological Institute 54: 881 p.

Received 19 September 2012; accepted 26 October 2012

Associate Editor: Maria Anice M. Sallum 